\title{
THE EFFECTS OF SELF-EFFICACY, ISLAMIC HUMAN CAPITAL, AND FINANCIAL LITERACY ON SME PERFORMANCE IN LAMONGAN EAST JAVA, INDONESIA
}

\author{
${ }^{1}$ Anang Kistyanto, ${ }^{2}$ Raja Zuraidah Rasi, ${ }^{3}$ Jun Surjanti, ${ }^{4}$ Tony Seno Aji \\ ${ }^{134}$ Faculty of Economics, Universitas Negeri Surabaya, \\ Jalan Ketintang Surabaya, Indonesia 60231
}
${ }^{2}$ Faculty of Technology Management and Business, Universiti Tun Hussein Onn Malaysia, Parit Raja, Batu Pahat, Johor Darul Ta'zim Malaysia 86400 1anangkistyanto@unesa.ac.id, ${ }^{2}$ rzuraida@uthm.edu.my, ${ }^{3}$ junsurjanti@unesa.ac.id, tonyseno@unesa.ac.id

\begin{abstract}
Abstack
The fishery sector has made important economic contributions to the island nation of Indonesia. In particular, small- and medium-sized enterprise (SME) fisheries, the owners of which are mostly Muslims with high school educations, have exhibited high self-confidence and effective development. However, the effects of other factors, such as self-efficacy, islamic human capital, and financial literacy, on SME performance have yet to be discussed in detail. Thus, this quantitative study examines the effects of self-efficacy, Islamic human capital and financial literacy on 31 SMEs in Lamongan, East Java. According to the results, self-efficacy had a significant effect on SME performance, whereas both Islamic human capital and financial literacy did not have an impact on such performance.
\end{abstract}

Keywords: Self-Efficacy, Islamic Human Capital, Financial Literacy, SME Performance

\section{Introduction}

The fishery sector has made and continues to make important contributions to the Indonesian economy (BPS, 2016). For example, according to the Central Statistics Agency, the Fishermen Exchange Rate in East Java increased from 106 in 2015 to 117.2 in 2017. Despite their economic contributions in the region, fishermen are still highly vulnerable to poverty. In this regard, Christyawaty (2001) found that the acquisition of fish has been uncertain, due to various aspects such as natural factors, price fluctuations, technology, and the limited education of the fishermen themselves. Moreover, Surjanti and Dian (2016) stated

Received: 2020-05-11 | Reviced: 2020-06-04| Accepted: 2020-06-22

Indexed : Sinta, DOAJ, Garuda, Crossref, Google Scholar | DOI: https://doi.org/10.29313/amwaluna.v4i2.6030 
that SME problems generally consist of natural constraints (raw materials), continuity of production, capital, marketing, and business transparency. The characteristics of SMEs, the characteristics of managers, and the way they do business are factors that also influence the success of SMEs in fishing families. This study will focus on self-efficacy and religious values on performance in fishing families. Previous research with the theme of self-efficacy found that the self-efficacy of Malay owner managers influenced entrepreneurial orientation (Mohd et al., 2014).

In regard to motivation and performance, Bandura and Locke (2003) found that self-efficacy and self-goals can increase such aspects, while Mohd et al. (2014) showed that self-efficacy can improve entrepreneurial orientation and decision-making. Both results are in line with Bandura (1997), who mentioned that self-efficacy affects an individual's behavior, motivation, success, and failure. Conversely, Vancouver et al. (2001) found that self-efficacy has no impact on business performance. Based on these findings, there is a gap in the literature regarding the impact of self-efficacy on business performance.

Lamongan in East Java is known for its high religious values, due to the large majority of Muslims in the region. In fact, based on 2015 data from the Indonesian Statistics Bureau, the total population of Lamongan was $1,338,441$, with 1,342,266 (99.7\%) Muslims. Thus, it is most likely that Islamic religious values have a significant impact on business performance, especially that of SMEs.

Several studies have proven the relationship between islamic human capital and organizational performance (Azmi, 2015; Rafiki et al., 2014; Azmi, 2010; Stephenson et al., 2010; Khan \& Sheikh, 2012). In addition to these studies, there are also other studies that state that the practice of human capital affects organizational performance. This study discusses the gap between conventional human capital and islamic human capital. This gap is the focus of this study, because there are vast differences in the objectives of human capital and Islamic human capital. Human capital only focuses on intangible assets while Islamic human capital focuses on the world and the hereafter. In addition to this research conducted in a different country namely Indonesia, this study included two other variables in the relationship between Islamic human capital and SME performance, namely self-efficacy and financial literacy. Another novelty of this 
research is to include two other variables in the relationship between Islamic human capital and SME performance, namely selfefficacy and financial literacy.

Muda et al. (2016) argued that human capital has a significant effect on business performance and the lifecycles of SMEs. As for Islamic human capital, which refers to achieving a balance between worldly and /afterlife affairs, several studies have shown that there is a relationship between such capital and organizational performance (Azmi, 2015; Rafiki et al., 2014). Hence, the present study fills the gap between conventional human capital and Islamic human capital, since both types include different goals.

In addition to self-efficacy and islamic human capital, SMEs face certain difficulties, due to the limited financial literacy of their owners. According to Lusardi and Mitchell (2007), financial literacy refers to financial knowledge that is used to achieve prosperity, while Chen \& Volpe (1998) defined this term as the knowledge used to manage finances for future prosperity. Moreover, Admoko et al. (2016), in their study on fish-based products and the performance of SMEs in Central Java, argued that financial literacy is important for improving business performance and increasing the sustainability of SMEs in the region. However, based on a 2013 survey by the Indonesia Financial Services Authority (OJK), only $21.84 \%$ of the Indonesian population had a sufficient level of financial literacy. In this regard, Coad and Tamvada (2012) indicated that the lack of knowledge and access to financial resources can hinder a company's ability to achieve goals and increase its corporate value.

Finally, Surjanti and Dian (2016), in her study on empowering fishermen communities in Lamongan, found that fishermen generally lacked knowledge in professional business management and that they poorly managed their day-to-day financial operations. Therefore, the present study examines the influence of selfefficacy, Islamic human capital, and financial literacy on the performance of SME fisheries in Lamongan, for the purpose of improving their economic conditions.

\section{Discussion}

\section{A. Literature Review}

According to Bandura (1997), selfefficacy (SE) refers to an individual's confidence in the ability to control his/her behavior and motivation, which, in turn, can improve their prosperity. Bandura (1997) also argued that, since this ability is 
controlled by clues and consequences related to one's social environment, various factors can be considered within each individual, while models outside each individual can be broadened into social learning theory.

Based on the notion of SE, society generally considers that people have the ability to deal with problems, as long as they exert more effort in facing such obstacles. However, if there is any lingering doubt, then personal shortcomings will along with the problems (Litt, 1988; Schunk, 1989). Similarly, Pillis and Reardon (2007), in their study on Irish and American entrepreneurs, found that some owners lacked the ability to successfully start their businesses, due to their weak personalities. Moreover, according to Ferla et al. (2009), the SE indicators of entrepreneurs include the following factors: scheduling, considering economic business trends, calculating profits and losses, updating business information, formulating proper business formulas, and measuring business sources.

Hashi and Bashiir (2009) defined Islamic human capital as the human capacity to carry out social and spiritual activities. In particular, the religion of Islam views human capital as an overall asset possessed by humans, which includes their nature, work skills, learning attitudes, and knowledge (e.g., training, education, and experience) that makes them more competitive and flexible. Moreover, Islamic human capital can only be formed through long-term education and training that focuses on productive talents, managerial skills, creative attitudes, and settlement techniques, all of which help improve the quality of the relationship between humans and God (Azmi, 2015). Therefore, we propose our first hypothesis:

H1. Self-Efficacy has a significant positive effect on SME Performance

The development of Islamic human capital is extremely important for organizations in large Muslim populations (Azmi, 2015; Azmi, 2010), due to the Islamic value of being harmonious and closely connected to one's community. Hashi and Bashiir (2009) found five concepts regarding Islamic human capital: 1) tawaduk, as the foundation of human capital development; 2) job promotions; 3) intelligence protection; 4) managerial techniques; and 5) moral education. Moreover, Azmi (2015) stated that Islamic human capital can be measured according to five aspects: 1) Islamic recruitment and selection practices; 2) Islamic training and development practices; 3) Islamic career development; 4) Islamic performance management; and 5) the practice of giving 
rewards in Islam. Finally, Rafiki et al. (2014) measured Islamic human capital based on four points: 1) business experience; 2) Islamic motivation; 3) Islamic business training; and 4) Islamic education. Therefore, we propose our second hypothesis:

H2. Islamic Human Capital has a significant positive effect on SME Performance.

As stated earlier, Lusardi and Mitchell (2007) defined financial literacy as the financial knowledge to achieve prosperity, while Chen \& Volpe (1998) defined this term as the ability to manage finances for future prosperity. In their study on financial literacy, Admoko et al. (2016) found that there was an influence of such literacy on the performance and sustainability of SMEs in Central Java. More specifically, the SMEs introduced a cooperative approach, which not only helped them overcome certain limitations, but also helped them compete in the global environment.

Although Fatoki (2014) found that most SME owners lack the ability to effectively make financial plans and create budgets, other studies indicated that there is a positive impact of financial literacy on control systems and business success. Based on Chen \& Volpe (1998), financial literacy can be measured according to four indicators: 1) basic knowledge of financial management; 2) credit management; 3) savings and investment management; and 4) risk management. In this case, basic knowledge of financial management refers to the process of managing business functions effectively and efficiently, while financial management can be divided into three phases: 1) financial planning; 2) implementation; and 3) evaluation.

Venkatraman and Ramanujan (1986) stated that company performance is a construct that broadly explains the effectiveness of an organization, while Cameron (1986) defined company performance as organizational effectiveness based on errors and assertiveness in legitimate activities. Moreover, other researchers, such as Rhodes and John (2004), indicated that organizational performance refers to the financial performance of an organization.

Company performance can also be differentiated according to the company's size. In this regard, Garengo et al. (2005) argued that SME performance must be considered differently from large organizations, since certain indicators of financial and non-financial performance are incompatible (Marchini, 1995 in Biazzo and 
Garengo, 2012). Moreover, previous research has shown that company performance is one of the most relevant constructs to examine in the business field (Rumelt et al., 1994), while other studies have shown that such performance is an important dependent variable (Richard et al., 2009; Cho and Pucik, 2005; Sila and Ebrahimpuor, 2005; Wiklund and Shepherd, 2003).

In general, organizational performance is based on financial and non-financial performance (Rhodes and John, 2004). In this regard, financial performance consists of corporate profits, such as return on assets, return on investment (ROI), and total profits, while non-financial performance includes job satisfaction, customer satisfaction, quality of service, and quality of performance. Moreover, Santos and Brito (2012) stated that financial performance includes three indicators: 1) profitability; 2) growth; and 3) market value. Meanwhile, non-financial performance is based on four indicators: 1) customer satisfaction; 2) employee satisfaction; 3) environmental performance; and 4) social performance.

Finally, previous studies have found that the best performance measurement for developing companies is annual sales growth (Davidson et al., 2006; Cowling,
2004; Wong and Aspinwall, 2004). Thus, the present study measures SME performance based on this aspect. Because of the varying purposes and SME performance, we also examine the effectiveness of financial literacy when influencing career success:

H3. Financial Literacy has a significant positive effect on SME Performance.

\section{B. Methods}

The research design in this study was explanatory research, because it was to analyze the effect of independent variable (self-efficacy, islamic human capital, financial literacy) on dependent variable (SME's performance). Questionnaire surveys to analyze 31 SME fisheries in Lamongan, all of which were selected through the saturated sampling technique. The analysis was divided into two stages. In the first stage, the outer model was assessed according to the acceptable levels of reliability and validity. As for the second stage, the inner model was measured according to R-square for endogenous latent variables and path coefficient values.

The instrument developed by Ferla et al. (2009) was used to measure self-efficacy, while the instrument developed by Rafiki et al. (2014) was used to measure Islamic human capital. Regarding the latter instrument, it consists of four indicators: 1) 
business experience; 2) Islamic motivation; 3) Islamic business training; and 4) Islamic education. Moreover, the instrument adapted from Chen \& Volpe (1998) was used to measure financial literacy, while the instrument from Cowling (2004) and Wong and Aspinwall (2004) was used to measure SME performance. As for the latter instrument, it consists of five dimensions: 1) profitability; 2) growth; 3) employee satisfaction; 4) customer satisfaction; and 5) environmental performance. Measurement data is assessed with a four-point Likert scale starting from (1) "strongly agree (SS), agree (S), disagree (TS), strongly disagree (STS). Validity and reliability tests were conducted to test the research instrument with a correlation value that was greater than 0.3 , and the alphabet coefficient was greater than 0.6. The hypothesized structural equations model was tested using Structure Equation Modeling Partial Least Square (SEM PLS) with software of SmartPLS 2.0.M3.

\section{Result}

The validity and reliability tests were conducted to measure the validity and reliability of the variables proposed by the researchers, namely: Islamic human capital, SE, financial literacy, and SME performance. In this case, each variable was measured according to various dimensions.
First, Islamic human capital was measured according to four dimensions (i.e., business experience, Islamic motivation, Islamic business training, and Islamic education), after which each variable was measured by using three indicators. Then, SE was measured by eight indicators, while financial literacy was measured according to four dimensions (i.e., basic knowledge of financial management, literacy on savings and credit, insurance, and investments), after which each variable was measured by using five indicators. Finally, SME performance was measured according to five dimensions (i.e., profitability, growth, employee satisfaction, customer satisfaction, and environmental performance), after which each variable was measure by using various indicators. Overall, the validity test determined whether the outer loading of each indicator exceeded 0.4 (the standard value), while the reliability test determined whether the values exceeded Cronbach's alpha of 0.6 , which indicates acceptable reliability.

The outer model evaluation was performed by examining two elements, namely: convergent validity and discriminant validity. In general, convergent validity is determined by examining the factor loadings and the average variance extracted (AVE), while discriminant 
validity is measured by examining the crossloading values. In the present study, all of the factor loadings met the standard value of 0.4, while all of the AVE values exceeded 0.5 , thus indicating that convergent validity was achieved. Based on the examination of the cross-loading values, discriminant validity was also achied.

The inner model was evaluated according to R-square for endogenous latent variables and path coefficient values, the results of which are shown in Tables 1 and 2.

Table 1. R-Square Results

\begin{tabular}{lc}
\hline & $R$-Square \\
\hline Islamic Human Capital & - \\
\hline Self-Efficacy & - \\
\hline Financial Literacy & - \\
\hline SME Performance & 0.224 \\
\hline
\end{tabular}

Source: Output partial least squares structural equation modeling (PLS-SEM) (2017)

According to Table 1, the R-square for SME performance is 0.224 , which indicates that it is influenced by Islamic human capital, SE, and financial literacy. The inner model was also measured through Q-square predictive relevance. Since the Q-square is greater than 0 , the model has predictive relevance on the exogenous and endogenous variables.

After evaluating the outer and inner models, bootstrapping was performed in order to determine the impact of each variable on SME performance. The effects of Islamic human capital (IHC), SE, and financial literacy (FL) on SME performance (SME P) are shown in Figure 1.

Figure 1.
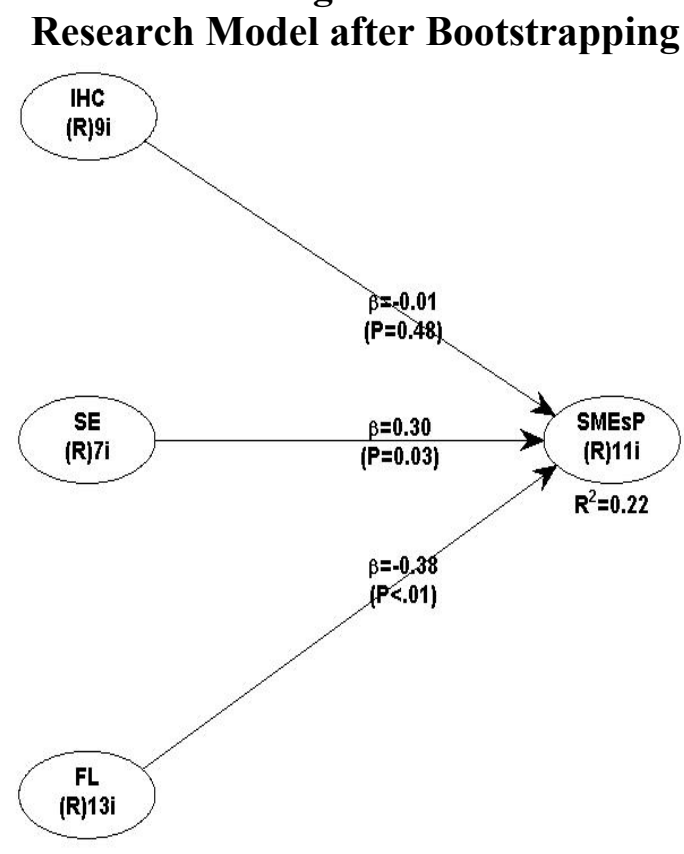

Source: Output PLS-SEM (2017)

Table 2.

Results of the Path Coefficient Test (MEAN, STDEV, T-Values) Path
Cofficient -Value

\section{Islamic}

Human

Capital -> $-0.008$ $P=$ SME 0.48

Performance

\begin{tabular}{lll}
\hline Self-Efficacy - & & $P=$ \\
$>$ SME & 0.297 & 0.03 \\
Performance & & \\
\hline $\begin{array}{ll}\text { Financial } \\
\text { Literacy }\end{array}$ & & $P<$ \\
- SME & -0.377 & 0.01 \\
Performance & & \\
\hline
\end{tabular}

Source: Output PLS-SEM (2017) 
According to Table 2, SE has a positive coefficient value of 0.297 , which indicates that it has a significant effect on SME performance. Moreover, the higher the SE, the better the SME performance. Hence, SE has a significant impact on SME performance. As for the variables of IHC and FL, they have negative coefficient values of -0.008 and -0.377 , respectively. Therefore, both IHC and FL do not have a significant effect on SME performance.

\section{Effect of Self-Efficacy on SME Performance}

Overall, the majority of the respondents indicated that SE improved their self-confidence in running their businesses. According to Surjanti et al. (2015), high SE has a significant effect on how SMEs deal with business-related issues (despite some reluctance in implementing economic theories). Similarly, Locke (1991) and Appelbaum and Hare (1996) found that goals, SE, and motivation are the three main pillars of SME performance, while Bandura (1997) stated that motivation is one of the important elements in cognitive social theory.

In regard to Bandura's cognitive social theory, Education (1996) found that there is a relationship between SE, motivation, and academic achievement, indicating that SMEs with high SE are generally motivated to improve their business performance. Based on these findings, SE has a positive impact on SME performance.

Effect of Islamic Human Capital on SME Performance

Among the respondents, one of the most important statements regarding IHC was by Syaiful Ustadi, a chicken ball seller: “.... I have this business solely due to Allah, as He is the One who blesses me with life and fulfills my needs, and by working I am able to meet my needs." Similarly, the husband of Lilik Chamidah, the owner of a chip factory, stated the following: “.... the one dealing with business and religion is my wife." Although these respondents acknowledged their faith and blessings, such acknowledgments did not necessarily improve or influence their business performance.

Theoretically, IHC is explainable by using the theory of work values, which has been defined as an individual's faith in facing his/her work environment (Meglino and Ravlin, 1998). Meanwhile, other researchers have mentioned that work values include altruistic values, relationshipstatus values, freedom-related values, and social values (Borg, 1990; Ros et al., 1999; and Lyons, 2004). 
According to Elizur (1984), work values consist of intrinsic and extrinsic values that affect an individual's work performance. Intrinsic values refer to the desire to develop and perform selfactualization in the workplace, while extrinsic values refer to the tendency to focus on important external activities such as achieving financial success, obtaining social recognition from co-workers, and exercising control and power (Deci and Ryan, 2000; Ryan and Deci, 2000). Moreover, Kasser and Ryan (1993, 1996) and Vansteenkiste et al. (2007) defined intrinsic orientation as an employee's natural desire to perform the following: to actualize, develop, and grow in the workplace (self-development); to build meaning and increase satisfaction in the relationships with colleagues (affiliation); and to help people in need (community contribution). Meanwhile, the focus on financial success and status reflects extrinsic orientation, since they are largely based on an individual's anticipation of personal admiration and self-esteem, which can only be realized through external activities (Kasser and Ryan, 1993; Ryan and Deci, 2000; Richins and Dawson, 1992).

As for IHC, as a type of intrinsic value, an individual not only works for materialistic needs, but also for self- development (i.e., being close to God). For example, Lilik Chamidah's business was for Allah and not necessarily for herself. Since this statement implies that there are differences in individual beliefs, perhaps future research should focus on different belief systems in running businesses.

Effect of Financial Lietracy on SME Performance

Based on the partial least squares structural equation modeling (PLS-SEM) in this study, FL has a negative impact on SME performance. In addition, the descriptive statistics showed that SME performance was categorized as medium. However, this result is in contrast to previous studies on the relationship between finacial literacy and business performance (Admoko et al., 2016; Chen \& Volpe, 1998; Patrick, 2015; Lusimbo \& Muturi, 2016; Chepngetich, 2016; and Ibrahim, 2017).

In the present study, the SME owners in Lamongan had good FL, but they had little to no access to financial facilities (e.g., insurance and investments) that could help them improve their businesses over the long run. This finding indicates that having FL is not necessarily comparable to having financial inclusion. In addition, Fatoki (2014) found that most SME activities are unrelated to financial plans, budgeting, and financial control, while Susan (2012) and 
Nkundabanyanga et al. (2014) mentioned that one of the major problems faced by SMEs is difficulty accessing credit or loans. However, some respondents in the present study preferred not to use such financial assistance. For example, one respondent stated the following: "...I prefer to work on my own, rather than accepting loans or capital from others, because profits or losses would be my own responsibility and no one else's..." Moreover, some of the respondents preferred more traditional methods of running a business. For instance, one SME owner stated: "I received some financial training from Ms. Dian, but it was too complicated. So, I prefer to use traditional methods, since they are much easier."

Based on these responses, the SME owners had an adequate level of FL, but they had little to no intention of implementing such knowledge in their businesses, thus resulting in low performance. The implication of this finding is that implementing FL initiatives will not only boost SME owners' self-confidence in running their businesses, but it will also improve the performance of their SMEs as a whole.

\section{Conclusion}

This quantitative study examined the effects of SE, IHC, and FL on the performance of 31 SMEs in Lamongan,
Indonesia. Based on the questionnaire surveys and the related analyses, SE had a positive effect on SME performance, since it motivated the owners to evaluate their business-related activities. Meanwhile, both IHC and FL had a negative effect on SME performance. As for IHC, although the respondents acknowledged their religious faith and blessings, such acknowledgment did not necessarily improve or influence their business performance. Regarding FL, the SME owners had an adequate level of financial knowledge, but they had little to no intention of implementing it in their businesses.

The implication of the findings is that SMEs should increase their SE as much as possible, while integrating their religious values into their business in order to improve overall performance. Moreover, SMEs should ideally implement FL initiatives, which will not only boost SME owners' self-confidence in running their businesses, but it will also improve the performance of their SMEs over the long run.

Further research could include refining islamic human capital and financial literacy data to determine which indicators of Islamic human capital and financial literacy determine the effect of SME performance. A deeper observation needs to 
be made to explore the effects of Islamic human capital and financial literacy on SME performance. Limitations of the study include the diverse characteristics of respondents, the sample size is still limited. A different approach to data collection might enable interaction and responses from participants.

\section{BIBLIOGRAPHY}

Admoko, S., Danso, A., \& Damoah, J. O. (2016). The moderating influence of Literasi Keuangan on the relationship between accesses to finance and firm Growth in Ghana. Venture Capital, 18(1), 43-61. https://doi.org/10.1080/13691066.201 5.1079952

Appelbaum, S. H., \& Hare, A. (1996). Self efficacy as a mediator of goal setting and performance: Some human resource applications. Journal of Mangerial Psychology, 11(3), 33-47. https://doi.org/10.1108/02683949610 $\underline{113584}$

Aribawa, D. (2016). Pengaruh Literasi Keuangan Terhadap Kinerja dan Keberlangsungan UMKM di Jawa Tengah. Siasat Bisnis, 20(1), 1-13. https://doi.org/10.20885/jsb.vol20.iss 1.art1

Azmi, I. A. G. (2010). Islamic Human Resource Practices and Organizational Performance: A Preliminary Finding of Islamic Organisations in Malaysia. Journal of Global Business and Economics, 1(1), 27-42.
Azmi, I. A. G. (2015). Islamic Human Resource Practices and Organizational Performance; Some Findings in Developing Country. Journal Islamic Accounting and Business Research, 6(1), 1-14. https://doi.org/10.1108/JIABR-022012-0010

Badan Pusat Statistik (BPS). (2016). Statistik Nilai Tukar Nelayan Provinsi Jawa Timur 2016. Https://Jatim.Bps.Go.Id/4dm!N/Pdf Publikasi/Statistik-Nilai-TukarNelayan-Provinsi-Jawa-Timur2016.Pdf. Diakses Tanggal 4 Juni 2017.

Bandura, A. (1977). Social Learning Theory, New Jersey. Prentice Hall, Inc.

Bandura, A. (1991). Social cognitive theory of self-regulation. Organizational Behavior and Human Decision Processes, $\quad 50(2), \quad$ 248-287. https://doi.org/10.1016/07495978(91)90022-1

Bandura, A. (1994). Self efficacy. In V. S. Ramachaudran (Ed.), Encyclopedia of human behavior (71-81). Academic Press. (Reprinted in H. Friedman [Ed.], Encyclopedia of mental health. Academic Press).

Bandura, A., Barbaranelli, C., Caprara, G. V., \& Pastrorelli, C. (1996). Multifaceted Impact of Self efficacybeliefs on academic functioning. Child Development, 67(3), 1206-1222. https://doi.org/10.2307/1131888

Bandura, A., \& Locke, E. A. (2003). Negative Self efficacy and Goal Effects Revisited. Journal of Applied Psychology. $\quad 88(1), \quad$ 87-99. http://doi.org/10.1037/00219010.88.1.87. 
Barnes, M., Dickinson, T., Coulton, L., Dransfield S., Field J., Fisher, N., Saunders, I., \& Shaw, D. (1998). A New Approach to Performance Measurement for Small Medium Enterprises. Performance Measurement - Theory and Practice (Conference Proceedings), 1, 86-92.

Beck, T., Demirguc-Kunt, A., \& Maksimovic, V. (2005). Financial and legal constraints to Growth: Does firm size matter? The Journal of Finance, $60(1)$, 137-177. https://doi.org/10.1111/j.15406261.2005.00727.x

Biazzo, S., \& Garengo, P. (2012). Performance Measurement with the Balance Scorecard A Practical Approach to Implementation within SMEs. SpringerBriefs in Business. https://doi.org/10.1007/978-3-642$\underline{24761-3}$

Bititci, U. S., Carrie, A. S., \& McDevitt, L. (1997). Integrated Performance Measurement Systems: a Development Guide. International Journal of Operatios \& Production Management, 17(5), 522-534. https://doi.org/10.1108/09544789710 159443

Borg, I. (1990). Multiple Facetisations of Work Values. International Association of Applied Psychology, 39(4), 401-412. https://doi.org/10.1111/j.14640597.1990.tb01063.x

Bourne, M. (2001). Implementation Issues Handbook of Performance Measurement. GEE Publishing Ltd.

Cameron, K. (1986). A Study of Organizational Effectiveness and its Predictors. Management Science, $32(1)$, 87-112. https://doi.org/10.1287/mnsc.32.1.87
Chen, H. \& Volpe, R. P. (1998). "An Analysis of Personal Literasi Keuangan among CollegeStudents." Financial Services Review, 7(2), 107128. https://doi.org/10.1016/S10570810(99)80006-7

Chepngetich, P. (2016). Effect of Financial Literacy and Performance SMEs. Evidence from Kenya. American Based Research Journal, 5(11), 2635.

http://dx.doi.org/10.5281/zenodo.344 $\underline{1820}$

Christyawaty, E. (2001). Kehidupan Keluarga Nelayanstudi Kasus 5 Keluarga Nelayan Di Desa Taluak Kecamatan Pariaman Selatan, Kabupaten Padang Pariaman Propinsi Sumatera Barat. Departemen Kebudayaan Dan Pariwisata. http://www.PustakaBpnbkalbar.Org/Pustaka/KehidupanKeluarga-Nelayan-Studi-Kasus-5Keluarga-Nelayan-Di-Desa-TaluakKecamatan-Pariaman\#. accessed on June 4, 2017.

Coad, A., \& Tamvada, J. P. (2012). Firm Growth and barriers to Growth among small firms in India. Small Business Economics, 39, 383-400. https://doi.org/10.1007/s11187-0119318-7

Cooper, A., Gimeno-Gascon, F. J., \& Woo, C. Y. (1994). Initial human and financial capital as predictors of new venture performance. Journal of Business Venturing, 9(5), 371-395. https://doi.org/10.1016/08839026(94)90013-2

Cowling, M. (2004). The Gowth-Profit Nexus. Small Business Economics, 22, 1-9.

https://doi.org/10.1023/b:sbej.000001 1568.42714.c9 
Davidson, P. M., Elliott, D., Daly, J., \& MEd (Hons). (2006). Clinical leadership in contemporary clinical practice: implications for nursing in Australia. Journal of Nursing Management, 14(3), 180-187. https://doi.org/10.1111/j.13652934.2006.00555.x

Dearden, L., Reed, H., \& Van Reenen, J. (2000). Who Gains when Workers Train? Training and Corporate Productivity in a panel of British industries.

https://doi.org/10.1920/wp.ifs.2000.0 004

Deci, E. L., \& Ryan, R. M. (2000). The 'What' and 'Why' of Goal Pursuits: Human Needs and the Selfdetermination of Behavior. Psychological Inquiry, 11, 227-268. https://doi.org/10.1207/s15327965pli 110401

Doucouliagos, C. (1997). The Agregate Demand for Labour in Australia: Meta-Analysis. Australian Economics Papers, 36(69), 224. https://doi.org/10.1111/j.14678454.1997.tb00847.x

Elizur, D. (1984). Facets of Work Values: A Structural Analysisof Work Outcomes. Journal of Applied Psychology, 69(3), 379-389. https://doi.org/10.1037/00219010.69.3.379

Fatoki, O. (2014). The Financial literacy of micro entrepreneurs in South Africa. Journal of Social Science, 40(2), 151158.

https://doi.org/10.1080/09718923.201 4.11893311

Ferla, D. J., Valcke, P. D. M., \& Cai, P. D. Y. (2009). Academic Self efficacyand academic self-concept: Reconsidering structural relationships. Learning and Individual Differences, 19(4), 499505.

http://doi.org/10.1016/j.lindif.2009.05 .004 .

Fitz-Enz, J. 2000. How to Leverage Your Human Capital ROI. $T \& P$ : Tooling and Production, 66, 28-43.

Garengo, P., Biazzo, S., \& Bititci, U. S. (2005). Performance Measurement System in SMEs: A Revie for a Research Agenda. International Journal of Management Reviews, 7(1), 25-47. https://doi.org/10.1111/j.14682370.2005.00105.x

Hashi, A. A., \& Bashiir, A. (2009). Human Capital Development from Islamic Perspective. Conference paper: International Conference on Human Capital Development, by UMP, Kuantan Pahang, Malaysia, 1-9.

Horgan, J., \& Muhlau, P. (2005). Human Resource Managementand Performance a Comparative Study of Irelandand Netherland. Management Review, 16(2), 242-258. https://doi.org/10.5771/0935-99152005-2-242

Hutchinson, J., \& Xavier, A. (2006). Comparing the impact of credit constraints on the Growth of SMEs in a transition country with an established market economy. Small Business Economics, 27(2/3), 169179. https://doi.org/10.1007/s11187$\underline{005-4412-3}$

Ibrahim, A. H. (2017). The Impact Of Financial Literacy On TheProfitability Of Micro And Small Enterprises Owned By University Students In Kenya: A CaseStudy Of United States Internasional 
University- Africa [Master's thesis, United States International University-Africa]. Digital Repository United States International University-Africa.

http://erepo.usiu.ac.ke/11732/3279

Kasser, T., \& Ryan, R. M. (1993). A Dark Side of the American Dream: Correlates of Financial Success as a Central Life Aspiration. Journal of Personality and Social Psychology, 65, 410-422.

https://doi.org/10.1037/00223514.65.2.410

Kasser, T., \& Ryan, R. M. (1996). Further Examining the American Dream: Differential Correlates of Intrinsic and Extrinsic Goals. Personality and Social Psychology Bulletin, 22, 280287.

https://doi.org/10.1177/01461672962 $\underline{23006}$

Khan, M. B., \& Sheikh, N. N. (2012). Human Resources development, motivation and Islam. Journal of Management Development, 31(10), 1021-1034.

http://dx.doi.org/10.1108/026217112 11281807

Kharisun, M. (2014). Karakteristik Dan Peran Istri Nelayan Dalam Pendapatan Keluarga Nelayan Di Kota Pekalongan [Undergraduate thesis, Universitas Diponegoro Semarang]. Eprints Universitas Diponegoro Semarang. https://Eprints.Undip.Ac.Id/43130/1/0 9 KHARISUN.pdf. Accessed on June 4, 2017.

Lambooij, M., Sanders, K., Koster, F., \& Zwiers, M. (2006). Human Resource Practices and Organizational Performance: Can HRMPerformancelinkage be Explained by the Cooperative Behaviours of Employees?. Management Review, 1(3), 223-240. https://doi.org/10.5771/0935-9915$\underline{\text { 2006-3-223 }}$

Litt, M. D. (1988). Self-efficacy and Perceived Control: Cognitive Mediators of Pain Tolerance. Journal of Personality and Social Psychology, 54(1), 149-160. https://doi.org/10.1037//0022$\underline{3514.54 .1 .149}$

Locke, E. A. 1991. "The motivational sequence, the motivation hub, and the motivation core". Organizational Behavior and Human Decision Processes, 50, 288-299. https://doi.org/10.1016/07495978(91)90023-m

Lusardi, A. \& Mitchell, O. S. (2007). Baby Boomer retirement security: The roles of planning, Literasi Keuangan, and housing wealth. Journal of Monetary Economics, 54, 205-224. https://doi.org/10.1016/j.jmoneco.200 $\underline{6.12 .001}$

Lusimbo, E. N., \& Muturi, W. (2016). Financial Literacy And The Growth Of Small Enterprises In Kenya: A Case Of Kakamega Central SubCounty, Kenya. International Journal of Economics, Commerce and Management, IV(6), 828-845.

Lyons, S. (2004). An Exploration of Generational Values in Life and at Work [Doctoral dissertation, Carleton University Ottawa, Ontario]. Carleton University Research Virtual Environment. https://doi.org/10.22215/etd/2004$\underline{05791}$

Magal, S. R., Kosalge, P., \& Levenburg, N. M. (2009). Using importance performance analysis to understand 
and guide e-business decision making in SMEs. Journal of Enterprise Information Management, 22(1), 137151.

http://doi.org/10.1108/174103909109 $\underline{32795}$

Manurung Jonni J., \& Adler H. Manurung, (2009). Ekonomi Keuangan dan Kebijakan Moneter (Cetakan Pertama). Salemba Empat.

Meglino, B. M., \& Ravlin, E. C. (1998). Individual Values in Organizations: Concept, Controversies, and Research. Journal of Management, 24, 351-389. https://doi.org/10.1177\%2F01492063 $\underline{9802400304}$

Mohd, R., Hisham, B., Muda, M., \& Hassan, S. (2016). Malay owner managers of SMEs : the typology. Procedia Economics and Finance, 37, 86-92. http://doi.org/10.1016/S22125671(16)30097-1.

Mohd, R., Kirana, K., Hisham, B., \& Zainuddin, A. (2014). The Mediatory Effect of Efikasi Diri on the Relationship between Religious Values and Entrepreneurial Orientations : A Case of Malay Owner Managers of SMEs in Manufacturing Industry. Procedia-Social and Behavioral Sciences, 130, 96-104. http://doi.org/10.1016/j.sbspro.2014.0 4.012.

Muda, S., Ridhuan, M., \& Abdul, C. (2016). Human Capital in SMEs Life Cycle Perspective. Procedia Economics and Finance, 35, 683-689. http://doi.org/10.1016/S22125671(16)00084-8.

Nkundabanyanga, K. S., Kasozi, D., \& Nalukenge, I. (2014). Lending terms, Literasi Keuangan, and formal credit accessibility. International Journal of Social Economics, 41(5), 342-361. https://doi.org/10.1108/ijse-03-2013$\underline{0075}$

Pajares, F. (1996). Self-efficacy beliefs in academic settings. Review of Educational Research, 66(4). https://doi.org/10.3102\%2F00346543 $\underline{066004543}$

Patrick, C. (2015). The Effect of Financial Literacy on Performance of Small And Medium Enterprises in Trans Nzoia County [Master's thesis, University of Nairobi]. Semanticscholar.

Pena, I. (2004). Business Incubation Centers and New Firm Growth in the Basque Country. Small Business Economics, 22(3/4), 223-236. https://doi.org/10.1023/b:sbej.000002 $\underline{2221.03667 .82}$

Jdih Jatimprov. (2016). Peraturan Pemerintah Nomor 3 Tahun 2016 Tentang Perlindungan Dan Pemberdayaan Nelayan. Http://Jdih.Jatimprov.Go.Id/?Wpfb $\underline{\mathrm{Dl}=17367 .}$ Accessed on Juni 4, 2017.

Pillis, E. D., \& Reardon, K. K. (2007). The influence of personality traits and persuasive messages on entrepreneurial intention: A crosscultural comparison. Career Development International, 12(4), 382-396.

http://doi.org/10.1108/136204307107 56762.

Rafiki, A., AlKhalifa, K., \& Buchari, I. (2014). Islamic human capital and firm performance: An evidence of small and medium enterprises in Bahrain. International Journal of Business and Management, 9(4), 173181. 
$\underline{\text { https://doi.org/10.5539/ijbm.v9n4p17 }}$ 3

Rhodes, C., \& John S, B. (2004). Understanding Self-Perception of Business Performance: An Examination of Black American Entrepreneurs. Journal of Developmental Entrepreneurship, $9(1), 55-71$.

Richard, P. J., Devinney, T. M., Yip, G. S., \& Johnson, G. (2009). Measuring Organizational Performance; Toward Methodological Best Practice. Journal of Management, 33(3), 718-804. https://doi.org/10.1177/01492063083 30560

Richins, M. L., \& Dawson, S. (1992). A Consumer Values Orientation for Materialism and Its Measurement: Scale Development and Validation. Journal of Consumer Research, 19, 303-316.

https://doi.org/10.1086/209304

Ros, M., Schwartz, S. H., \& Surkiss, S. (1999). Basic Individual Values, Work Values, and the Meaning of Work. Applied Psychology AN International Review, 48(1), 49-71. https://doi.org/10.1111/j.14640597.1999.tb00048.x

Rumelt, R. P., Schendel, D. E., \& Tece, D. J. (1994). Fundamental Issues in Strategy: A research agenda. Long Range Planning, 28(1), 125. https://doi.org/10.1016/0024$\underline{\text { 6301(95)92107-9 }}$

Ryan, R. M., \& Deci, E. L. (2000). SelfDetermination Theory and the Facilitation of Intrinsic Motivation, Social Development and Well-Being. American Psychologist, 55, 68-78. https://doi.org/10.1037/0003$\underline{066 x .55 .1 .68}$
Santos, J. B., \& Brito, L. A. L. (2012). Toward a Subjective Measurement Model for Firm Performance. Brazilian Administration Review, 9(6), $\quad 95 \quad 117$. http://dx.doi.org/10.1590/S180776922012000500007

Schunk, D. H. (1989). Self-efficacy and achievement behaviors. Educational Psychology Review, 1, 173-208. https://doi.org/10.1007/bf01320134

Seleim, A., Ashour, A., \& Bontis, N. (2007). Human Capital and Organizational Performance: A Study of Egyptian Software Companies. Management Decision, 45(4), 789-801. https://doi.org/10.1108/00251740710 $\underline{746033}$

Sila, I., \& Ebrahimpour, M. (2005). Critical Linkages among TQM Factors and Business Results. International Journal of Operation and Production Management, 23(11), 1123-1155. https://doi.org/10.1108/01443570510 $\underline{626925}$

Surjanti, J., Dian A. N., Rahayu Dewi S. Y., \& Rosa P. J. (2016). Pengembangan Produk Unggulan Daerah melalui Pendampingan Kelompok Bisnis Makanan Berbahan Dasar Ikan di Kabupaten Lamongan. MP3EI.

Surjanti, J., \& Nuswantara, D. A. (2016). Pemberdayaan sociopreneurship masyarakat nelayan (Studi pada UKM "Crispy Ikan Sunduk" Kabupaten Lamongan). In I. W. Susila, S. Suroto, \& T. Tukiran (Eds.), Prosiding Seminar Nasional Hasil Penelitian dan Pengabdian Kepada Masyarakat. FMIPA dan LPPM UNESA Surabaya.

Stephenson, M. L., Russell, K. A., \& Edgar, D. (2010). Islamic hospitality in the UAE: Indigenization of products and 
human capital. Journal of Islamic Marketing, $\quad 1(1), \quad 9-24$. http://dx.doi.org/10.1108/175908310 $\underline{11026196}$

Susan, N. P. (2012). Credit Terms, Access to Finance and Financial Performance of SMEs in Kampala. Makerere University.

Uygur, S. (2009). The Islamic Work Ethic and the Emergence of Turkish SME Owner-Managers. Journal of Business Ethics, $\quad 88(1), \quad 211-225$. https://doi.org/10.1007/s10551-0090107-z

Vancouver, J. B., Thompson, C. M., \& Williams, A. A. (2001). The changing signs in the relationships among selfefficacy, personal goals, and performance. Journal of Applied Psychology, 86(4), 605-620. https://doi.org/10.1037/00219010.86.4.605

Vansteenkiste, M., Neyrinck, B., Niemic, C. P., Soenens, B., Witte, H. D., \& Broeck, A. V. D. (2007). On the Relations among Work Values Orientations, Psychological Need Satisfaction and Job Outcomes: A Self-Determination Theory Approach. Journal of Occupational and Organizational Psychology, 80(2), 251-277.

https://doi.org/10.1348/096317906X1 $\underline{11024}$

Venkatraman, N., \& Ramanujam, V. (1986). Measurement of Business Economic Performance: an Examination Method Convergent. Journal of Management, 13(1), 109-122. https://doi.org/10.1177\%2F01492063 $\underline{8701300109}$

Wageman, R., \& Gordon, F. M. (2005). As the Went is Bent: How Group Values
Shape Emergent Task Interdependence in Groups. Organization Science, 16, 686-700. https://doi.org/10.1287/orsc.1050.014 $\underline{6}$

Wiklund, J., Patzelt, H., \& Shepherd, D. A. (2009). Building an integrative model of small business Growth. Small Business Economics, 32, 351-374. https://doi.org/10.1007/s11187-0079084-8

Wiklund, J., \& Shepherd, D. (2003). Knowledge-Based Resources, Entrepreneurial Orientation, and the Performance of Small and MediumSeized Business. Strategic Managament Journal, 24(13), 13071314. https://doi.org/10.1002/smj.360

Wong, K. Y., \& Aspinwall, E. 2004. Characterizing Knowledge Management in the Small Business Environment. Journal of Knowledge Management, 8(3), 44-61. https://doi.org/10.1108/1367327041054103 $\underline{3}$ 